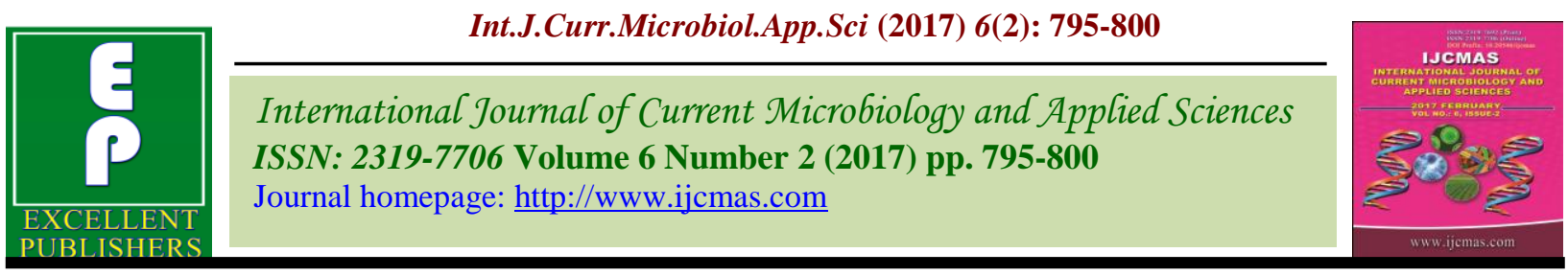

Original Research Article

http://dx.doi.org/10.20546/ijcmas.2017.602.088

\title{
Estimating Combining Ability for Yield and Yield Contributing Traits in Snake Gourd (Trichosanthes cucumerina L.)
}

\author{
N. Deepa Devi*, S. Mariappan, T. Arumugam and C.R. Anandakumar \\ Horticultural College and Research Institute, Tamil Nadu Agricultural University, \\ Coimbatore- 641003, India \\ *Corresponding author
}

\begin{abstract}
A B S T R A C T
Keywords

Snake gourd, Trichosanthus cucumerina L., Combining ability, LxT, Gene action.

Article Info

Accepted:

18 January 2017 Available Online: 10 February 2017

Line $\mathrm{x}$ Tester analysis was carried out for thirteen diversified parents at the department of Horticulture, Agricultural College and Research Institute, Madurai, Tamil Nadu, to study the combining ability for yield and yield contributing characters in snake gourd. The analysis for combining ability revealed significant mean sum of squares of both general combining ability (GCA) and specific combining ability (SCA) for all the characters which indicate that the presence of both additive and non-additive gene actions. The line IC $284753\left(\mathrm{~L}_{5}\right)$ and IC333314 $\left(\mathrm{L}_{2}\right)$ were found to be best general combiners, for majority of the yield and yield contributing characters. Among the testers Kumbakonam Local $\left(\mathrm{T}_{3}\right)$, Kulithalai Local $\left(\mathrm{T}_{1}\right)$ and Jeyamkondam Local $\left(\mathrm{T}_{2}\right)$ were found to be good general combiner for yield contributing characters viz., vine length, fruit length, fruit girth, average fruit weight, number of fruits per vine, number of seeds per fruit and yield per vine. Among the hybrids $\mathrm{L}_{2} \mathrm{xT}_{3}, \mathrm{~L}_{7} \mathrm{xT}_{2}, \mathrm{~L}_{2} \mathrm{xT}_{4}, \mathrm{~L}_{5} \mathrm{xT}_{1}$ and $\mathrm{L}_{8} \mathrm{xT}_{4}$ were found to be the good specific combiners $(\mathrm{gca})$ for most of the yield and yield contributing characters. These cross combinations can be utilized for further breeding programme for crop improvement in snake gourd.
\end{abstract}

\section{Introduction}

Snake gourd (Trichosanthes cucumerina L.) belongs to the family Cucurbitaceae and it's an important summer vegetable but it can be grown throughout the year except extreme winter. It is important as a good sources of minerals, fiber and nutrients to make the food wholesome and healthy (Ahmed et al., 2004). It is also one of the important vegetables which fetch more yields per unit area but the average yield of the crop is low. In addition it has got tremendous export potential because of its excellent keeping quality and shelf life. There are a number of cultivars with wide range of variability in size, shape and color of fruits available in this country. A large number of local lines are cultivated in the country but there is no recommended cultivar so far. There is no serious attempts have been made to upgrade the productivity of snake gourd. For developing superior varieties, it is necessary to improve the yield and its components in snake gourd. Yield is a complex character and is associated with some yield contributing characters, which are simple inherited (Rao et al., 2004). This can be achieved through effective utilization of germplasm resources and integration of genomic tools to impart efficiency and pace 
of breeding processes (Banga, 2012). Combining ability analysis has greater importance in crop improvement to identification of best combiners and utilize them in hybridization programme to produce superior hybrids, either to exploit for heterosis or to combine favourable genes (Meena et al., 2015). This technique was developed by Kempthorne in 1957. In addition, the information on nature of gene action will be helpful to develop efficient crop improvement programme. General combining ability is due to additive and additive $\times$ additive gene action and is fixable in nature while specific combining ability is due to non-additive gene action which may be due to dominance or epistasis or both and is non-fixable. The presence of non-additive genetic variance is the primary justification for initiating the hybrid breeding programme (Pali and Mehta, 2014). Keeping these points in view, the present investigation was undertaken to determine general combining ability and specific combining ability in snake gourd.

\section{Materials and Methods}

The present investigation was conducted in the Department of Horticulture, Agricultural College and Research Institute, Madurai, Tamil Nadu, during the period 2012-13. Study comprise of thirteen parents (nine lines and four testers) and these lines and testers (Table1) were crossed in LxT (Line x Tester) design to generate $36 \mathrm{~F}_{1}$ hybrids (crosses). These $36 \mathrm{~F}_{1}$ hybrids along with 13 parents were evaluated in randomized block design with three replications. These parents and hybrid seeds were sown at a spacing of $2 \mathrm{~m} \mathrm{x}$ $2 \mathrm{~m}$ with recommended package of practices followed as per the state of Tamil Nadu. Observations were recorded on five randomly tagged plants in each entry on vine length, fruit length, fruit girth, average fruit weight, number of fruits per vine, number of seeds per fruit and yield per vine. The data were analyzed for combining ability model of Kempthorne (1957).

\section{Results and Discussion}

The results revealed that significant differences existed among the genotypes and the parents for all the characters. The variance due to the lines was significant for all the traits under the study, indicating that the existence of enormous amount of genetic variability for growth, earliness and yield traits among the lines (female), Similarly, testers (male) and interaction between lines $\mathrm{x}$ testers exhibited significant differences for all the traits.

In the present study, the line $\mathrm{L}_{5}$ was adjudged as the best general combiner, since it expressed significant gca effects for four characters viz., fruit length, average fruit weight, number of fruits per vine and fruit yield per vine. The next best general combiner was $\mathrm{L}_{2}$ with high $g c a$ for two characters viz., fruit length and number of fruits per vine. This was followed by $\mathrm{L}_{1}$ (average fruit weight), $\mathrm{L}_{4}$ (yield per vine), $\mathrm{L}_{8}$ (fruit girth) which showed good general combining ability for different traits. Among the lines, IC $284753\left(\mathrm{~L}_{5}\right)$ and IC $333314\left(\mathrm{~L}_{2}\right)$ were also considered as good general combiners, because of high gca values for most of the yield and yield contributing characters. Among the testers, $\mathrm{T}_{2}$ was adjudged to be the good general combiner, as it showed significantly favourable $g c a$ effect for traits such as vine length, average fruit weight and number of fruits per vine. The next best was $T_{3}$ with good general combining ability for two traits viz., number of seeds per fruit and fruit yield per vine and $T_{1}$ for average fruit weight and number of fruits per vine. 
Table.1 Details of the parents used in the present study

\begin{tabular}{|c|c|c|c|}
\hline S. No. & Name of the parents & Source & Symbol \\
\hline \multicolumn{4}{|c|}{ Lines } \\
\hline 1. & IC413017 & NBPGR, New Delhi & $\mathrm{L}_{1}$ \\
\hline 2. & IC333314 & NBPGR, New Delhi & $\mathrm{L}_{2}$ \\
\hline 3. & IC433526 & NBPGR, New Delhi & $\mathrm{L}_{3}$ \\
\hline 4. & IC308557 & NBPGR, New Delhi & $\mathrm{L}_{4}$ \\
\hline 5. & IC284753 & NBPGR, New Delhi & $\mathrm{L}_{5}$ \\
\hline 6. & IC546083 & NBPGR, New Delhi & $\mathrm{L}_{6}$ \\
\hline 7. & IC410160 & NBPGR, New Delhi & $\mathrm{L}_{7}$ \\
\hline 8. & IC202159 & NBPGR, New Delhi & $\mathrm{L}_{8}$ \\
\hline 9. & IC212527 & NBPGR, New Delhi & $\mathrm{L}_{9}$ \\
\hline \multicolumn{4}{|c|}{ Tester } \\
\hline 1. & Kulithalai Local & Tamil Nadu & $\mathrm{T}_{1}$ \\
\hline 2. & Jeyamkondam Local & Tamil Nadu & $\mathrm{T}_{2}$ \\
\hline 3. & Kumbakonam local & Tamil Nadu & $\mathrm{T}_{3}$ \\
\hline 4. & $\begin{array}{l}\text { Palayajeyankondam } \\
\text { Local }\end{array}$ & Tamil Nadu & $\mathrm{T}_{4}$ \\
\hline
\end{tabular}

Table.2 General combining ability effects of parents

\begin{tabular}{|c|c|c|c|c|c|c|c|}
\hline Parents & $\begin{array}{l}\text { Vine length } \\
\text { (cm) }\end{array}$ & $\begin{array}{l}\text { Fruit length } \\
(\mathbf{c m})\end{array}$ & $\begin{array}{l}\text { Fruit girth } \\
\quad(\mathrm{cm})\end{array}$ & $\begin{array}{c}\text { Average } \\
\text { fruit weight } \\
\text { (g) }\end{array}$ & $\begin{array}{l}\text { Number of } \\
\text { fruits per } \\
\text { vine }\end{array}$ & $\begin{array}{l}\text { Number of } \\
\text { seeds per } \\
\text { fruit }\end{array}$ & $\begin{array}{l}\text { Yield per } \\
\text { vine }(\mathbf{k g})\end{array}$ \\
\hline \multicolumn{8}{|c|}{ Line } \\
\hline $\mathbf{L}_{1}$ & $0.50 *$ & $0.26 * *$ & $-0.77 * *$ & $-61.67 * *$ & $-1.44 * *$ & $12.56 * *$ & $-5.49 * *$ \\
\hline $\mathbf{L}_{2}$ & $5.19 * *$ & $-4.04 * *$ & $0.58 * *$ & $25.58 *$ & $4.30 * *$ & $3.11 * *$ & $-2.35 * *$ \\
\hline $\mathbf{L}_{3}$ & $-1.16 * *$ & $-2.41 * *$ & $-2.71 * *$ & $69.33 * *$ & 0.62 & $-10.82 * *$ & $-3.10 * *$ \\
\hline $\mathbf{L}_{4}$ & $4.78 * *$ & $-1.85 * *$ & $0.78 * *$ & $21.83 \mathrm{NS}$ & $-4.10 * *$ & $1.76 * *$ & $3.37 * *$ \\
\hline $\mathbf{L}_{5}$ & $-1.91 * *$ & $-9.71 * *$ & -0.44 & $-124.67 * *$ & $4.56 * *$ & $0.12 \mathrm{NS}$ & $3.52 * *$ \\
\hline $\mathbf{L}_{6}$ & $-2.41 * *$ & $6.89 * *$ & -0.16 & $6.83 \mathrm{NS}$ & 0.54 & $-0.77 * *$ & $2.68 * *$ \\
\hline $\mathbf{L}_{7}$ & $1.34 * *$ & $-1.41 * *$ & $0.52 * *$ & $-8.42 \mathrm{NS}$ & $-3.44 * *$ & $-13.85 * *$ & $2.46 * *$ \\
\hline $\mathbf{L}_{8}$ & -0.41 & $14.63 * *$ & $0.87 * *$ & $86.58 * *$ & $-1.26 * *$ & $10.31 * *$ & $-0.04 \mathrm{NS}$ \\
\hline$L_{9}$ & $-5.91 * *$ & $-2.35 * *$ & $1.32 * *$ & $-15.42 \mathrm{NS}$ & 0.22 & $-2.42 * *$ & $-1.03 * *$ \\
\hline SE & 0.2329 & 0.0932 & 0.0777 & 11.1816 & 0.4425 & 0.0834 & 0.0861 \\
\hline \multicolumn{8}{|c|}{ Tester } \\
\hline$T_{1}$ & $-1.31 * *$ & $0.18 * *$ & -0.34 & $-33.33 * *$ & $1.15 * *$ & $2.92 * *$ & $-0.63 * *$ \\
\hline$T_{2}$ & -0.12 & $-4.95 * *$ & $0.93 * *$ & $-26.11 * *$ & 0.29 & $1.36 * *$ & $-0.50 * *$ \\
\hline $\mathbf{T}_{3}$ & $-0.92 * *$ & $1.50 * *$ & $0.82 * *$ & $42.33 * *$ & $-0.81 * *$ & -6.56 ** & $0.68 * *$ \\
\hline $\mathbf{T}_{4}$ & $2.36 * *$ & $3.27 * *$ & $-1.41 * *$ & $17.11 *$ & $-0.64 *$ & $2.27 * *$ & $0.46 * *$ \\
\hline SE & 0.1553 & 0.0621 & 0.0518 & 7.4544 & 0.2950 & 0.0556 & 0.0574 \\
\hline
\end{tabular}

* Significant at $5 \%$ level

**Significant at $1 \%$ level 
Table.3 Specific combining ability effects of hybrids

\begin{tabular}{|c|c|c|c|c|c|c|c|}
\hline Hybrids & $\begin{array}{c}\text { Vine } \\
\text { length } \\
(\mathrm{cm})\end{array}$ & $\begin{array}{c}\text { Fruit } \\
\text { length } \\
(\mathrm{cm})\end{array}$ & $\begin{array}{c}\text { Fruit } \\
\text { girth }(\mathbf{c m})\end{array}$ & $\begin{array}{c}\text { Average } \\
\text { fruit weight } \\
\text { (g) }\end{array}$ & $\begin{array}{l}\text { Number } \\
\text { of fruits } \\
\text { per vine }\end{array}$ & $\begin{array}{l}\text { Number } \\
\text { of seeds } \\
\text { per fruit }\end{array}$ & $\begin{array}{l}\text { Yield per } \\
\text { vine (kg) }\end{array}$ \\
\hline $\mathbf{L}_{1 \times} \mathbf{T}_{1}$ & 2.35 & $-12.16 * *$ & $2.28 * *$ & $45.33 *$ & $2.48 * *$ & $-1.59 * *$ & $-0.08 \mathrm{NS}$ \\
\hline $\mathbf{L}_{1 \times} \mathbf{T}_{2}$ & $-7.39 * *$ & $19.43 * *$ & $-2.64 * *$ & 14.11 & $0.26 \mathrm{NS}$ & $5.14 * *$ & $0.12 \mathrm{NS}$ \\
\hline $\mathbf{L}_{\mathbf{1} \times} \mathbf{T}_{\mathbf{3}}$ & $3.41 * *$ & $-7.18 * *$ & $0.17 \mathrm{NS}$ & $-80.33 * *$ & $3.31 * *$ & $0.95 * *$ & $-2.49 * *$ \\
\hline $\mathbf{L}_{1 \times} \mathbf{T}_{4}$ & 1.63 & $-0.09 \mathrm{NS}$ & $0.19 \mathrm{NS}$ & 20.89 & $3.13 * *$ & $-4.50 * *$ & $-2.96 * *$ \\
\hline $\mathbf{L}_{2} \times T_{1}$ & 2.16 & $11.34 * *$ & $3.18 * *$ & -15.92 & $2.49 * *$ & $6.02 * *$ & $0.10 \mathrm{NS}$ \\
\hline $\mathbf{L}_{2 \times} \mathbf{T}_{2}$ & 2.47 & $9.88 * *$ & $-2.14 * *$ & -24.14 & $1.08 \mathrm{NS}$ & $-4.50 * *$ & $2.04 * *$ \\
\hline $\mathbf{L}_{2 \times} \mathbf{T}_{3}$ & $4.82 * *$ & $-11.18 * *$ & $1.67 * *$ & $82.42 * *$ & $2.58 * *$ & $3.39 * *$ & $-2.19 * *$ \\
\hline $\mathbf{L}_{2 \times} \mathbf{T}_{4}$ & $-9.46 * *$ & $-10.04 * *$ & $-2.71 * *$ & -42.36 & $-1.77 \mathrm{NS}$ & $-5.16 * *$ & $0.05 \mathrm{NS}$ \\
\hline $\mathbf{L}_{3 \times} \mathbf{T}_{1}$ & -1.44 & $-14.13 * *$ & $-3.43 * *$ & 4.33 & $3.13 * *$ & $-6.01 * *$ & $-2.96 * *$ \\
\hline $\mathbf{L}_{3} \times \mathbf{T}_{2}$ & 2.37 & $-4.75 * *$ & $1.90 * *$ & 7.11 & $3.32 * *$ & $7.78 * *$ & $-2.50 * *$ \\
\hline $\mathbf{L}_{3} \times \mathbf{T}_{\mathbf{3}}$ & 1.17 & $1.50 * *$ & $1.11 * *$ & 14.67 & $-2.81 * *$ & $-4.50 * *$ & $1.67 * *$ \\
\hline $\mathbf{L}_{3 \times} \mathbf{T}_{4}$ & -2.11 & $17.38 * *$ & $0.43 * *$ & -26.11 & $-3.64 * *$ & $-4.83 * *$ & $3.78 * *$ \\
\hline $\mathbf{L}_{4} \times T_{1}$ & $3.62 * *$ & $8.36 * *$ & $-1.07 * *$ & $111.83 * *$ & $-3.05 * *$ & $5.08 * *$ & $-0.95 * *$ \\
\hline $\mathbf{L}_{4 \times} \mathbf{T}_{2}$ & $4.18 * *$ & $-13.31 * *$ & $0.66 * *$ & $4.61 \mathrm{NS}$ & $-2.95 * *$ & $4.85 * *$ & $0.77 * *$ \\
\hline $\mathbf{L}_{4} \times \mathbf{T}_{3}$ & 2.23 & $-1.27 * *$ & $0.77 * *$ & $-37.83 \mathrm{NS}$ & $-2.03 * *$ & $2.94 * *$ & $-1.15 * *$ \\
\hline $\mathbf{L}_{4 \times} \mathbf{T}_{4}$ & $-10.04 * *$ & $6.22 * *$ & $-0.36 *$ & $-78.61 * *$ & $0.75 \mathrm{NS}$ & $-2.07 * *$ & $1.33 * *$ \\
\hline $\mathbf{L}_{5} \times T_{1}$ & $-7.69 * *$ & $8.07 * *$ & $0.90 * *$ & $-16.67 \mathrm{NS}$ & $5.03 * *$ & $10.57 * *$ & $1.18 * *$ \\
\hline $\mathbf{L}_{5 \times} \mathbf{T}_{2}$ & $5.12 * *$ & $-2.55 * *$ & $-2.07 * *$ & $51.11 *$ & $-2.28 *$ & $15.46 * *$ & $1.61 * *$ \\
\hline $\mathbf{L}_{5} \times \mathbf{T}_{3}$ & $3.92 * *$ & $-8.40 * *$ & $-0.06 \mathrm{NS}$ & $7.67 \mathrm{NS}$ & $-2.17 *$ & $-26.56 * *$ & $-0.57 * *$ \\
\hline $\mathbf{L}_{5} \times T_{4}$ & -1.36 & $2.88 * *$ & $1.22 * *$ & $-42.11 \mathrm{NS}$ & $2.70 * *$ & $0.53 * *$ & $-2.22 * *$ \\
\hline $\mathrm{L}_{6 \times} \mathrm{T}_{1}$ & -1.19 & $6.92 * *$ & $-2.28 * *$ & $-23.17 \mathrm{NS}$ & $2.27 * *$ & $1.37 * *$ & $-1.43 * *$ \\
\hline $\mathbf{L}_{6} \times T_{2}$ & $-12.38 * *$ & $-12.35 * *$ & $4.70 * *$ & 19.61 NS & $0.34 \mathrm{NS}$ & $-6.81 * *$ & $1.52 * *$ \\
\hline $\mathbf{L}_{6 \times} \mathrm{T}_{3}$ & $7.42 * *$ & $17.00 * *$ & $-2.39 * *$ & $-22.83 N S$ & $0.60 \mathrm{NS}$ & $5.96 * *$ & $2.48 * *$ \\
\hline $\mathrm{L}_{6 \times} \mathrm{T}_{4}$ & $6.14 * *$ & $-11.57 * *$ & $-0.02 \mathrm{NS}$ & $26.39 \mathrm{NS}$ & $-0.68 \mathrm{NS}$ & $-0.52 * *$ & $-2.57 * *$ \\
\hline $\mathbf{L}_{7 \times} \mathbf{T}_{1}$ & 2.06 & $-3.23 * *$ & $-0.06 \mathrm{NS}$ & $72.08 * *$ & $0.29 \mathrm{NS}$ & $-9.27 * *$ & $4.26 * *$ \\
\hline $\mathbf{L}_{7 \times} \mathbf{T}_{2}$ & $3.87 * *$ & $13.75 * *$ & $0.06 \mathrm{NS}$ & $34.86 \mathrm{NS}$ & $3.66 * *$ & $-3.61 * *$ & $-2.49 * *$ \\
\hline $\mathbf{L}_{7 \times} \mathbf{T}_{\mathbf{3}}$ & $-4.33 * *$ & $-1.20 * *$ & $-2.13 * *$ & $-58.58 *$ & $0.14 \mathrm{NS}$ & $13.29 * *$ & $-1.52 * *$ \\
\hline $\mathbf{L}_{7 \times} \mathbf{T}_{4}$ & -1.61 & $-9.32 * *$ & $2.13 * *$ & $-48.36 *$ & $-0.48 \mathrm{NS}$ & $-0.41 *$ & $-0.25 \mathrm{NS}$ \\
\hline $\mathbf{L}_{8 \times} T_{1}$ & $-5.19 * *$ & $0.83 * *$ & $0.94 * *$ & $-102.92 * *$ & $-5.73 * *$ & $-9.27 * *$ & $-3.25 * *$ \\
\hline $\mathbf{L}_{8} \times T_{2}$ & $6.62 * *$ & $-2.04 * *$ & $-1.48 * *$ & $-160.14 * *$ & $-1.49 \mathrm{NS}$ & $-3.61 * *$ & $-1.83 * *$ \\
\hline $\mathbf{L}_{8 \times} T_{3}$ & $-7.58 * *$ & $-8.64 * *$ & $2.78 * *$ & $121.42 * *$ & $3.46 * *$ & $13.29 * *$ & $2.99 * *$ \\
\hline $\mathbf{L}_{8 \times} T_{4}$ & $6.14 * *$ & $9.85 * *$ & $-2.24 * *$ & $141.64 * *$ & $3.76 * *$ & $-0.41 *$ & $2.09 * *$ \\
\hline $\mathrm{L}_{9 \times} \mathrm{T}_{1}$ & $5.31 * *$ & $-5.99 * *$ & $-0.46 * *$ & $-74.92 * *$ & $3.23 * *$ & $-0.26 \mathrm{NS}$ & $3.12 * *$ \\
\hline $\mathbf{L}_{9} \times T_{2}$ & $-4.88 * *$ & $-8.06 * *$ & $1.02 * *$ & $52.86 *$ & $1.67 \mathrm{NS}$ & $-0.54 * *$ & $0.76 * *$ \\
\hline$L_{9 x} T_{3}$ & $-11.08 * *$ & $19.38 * *$ & $-1.92 * *$ & $-26.58 \mathrm{NS}$ & $0.22 \mathrm{NS}$ & $2.60 * *$ & $-1.47 * *$ \\
\hline $\mathbf{L}_{9} \times T_{4}$ & $10.64 * *$ & $-5.33 * *$ & $1.36 * *$ & $48.64 *$ & $-2.88 * *$ & $-1.79 * *$ & $-2.42 * *$ \\
\hline SEd & 0.4658 & 0.1864 & 0.1554 & 22.3632 & 0.8850 & 0.1667 & 0.1723 \\
\hline
\end{tabular}

*Significant at $5 \%$ level

**Significant at $1 \%$ level 
From the above points, it could be inferred that IC $284753\left(\mathrm{~L}_{5}\right), \quad$ IC $333314\left(\mathrm{~L}_{2}\right)$, Jeyamkondam Local $\left(\mathrm{T}_{2}\right)$, Kumbakonam Local $\left(\mathrm{T}_{3}\right)$ and Kulithalai Local $\left(\mathrm{T}_{1}\right)$ were the best general combiners, since they expressed good gca effects for majority of the yield and yield contributing characters.

These parents could be used in the breeding programme to improve yield along with yield contributing characters. It may be inferred that the yield contributing genotypes can maintain their superiority in combining ability effects. The ratio of GCA and SCA exhibited non-additive gene action for vine length, fruit length, fruit girth, average fruit weight, number of fruits per vine, number of seeds per fruit and yield per vine. This was also reported by Dubey and Maurya (2007) and Suganthi (2008) in bottle gourd, Sarkar and Sirohi (2010) in cucumber, Podder (2010) in snake gourd, Vegad et al., (2011) in bottle gourd, Alli Rani (2013) in ridge gourd, Singh et al., (2013) in bitter gourd and Narasannavar (2014) in ridge gourd, and Bairwa et al., (2015) in ridge gourd. Such an absence of parallelism may be due to epistatic interactions.

Among the hybrid $\mathrm{L}_{2} \mathrm{XT}_{3}$ and $\mathrm{L}_{7} \mathrm{xT}_{2}$ excelled with superior $s c a$ effects for five characters viz., vine length, fruit length, fruit girth, number of seeds per fruit and number of fruits per vine. The crosses $\mathrm{L}_{2} \mathrm{xT}_{4}, \mathrm{~L}_{5} \mathrm{xT}_{1}$ and $\mathrm{L}_{8} \mathrm{xT}_{4}$ were identified as the next best specific combiners for most of the yield contributing characters. The sca effects of hybrids have been attributed to the combination of positive favourable genes from different parents or might be due to the presence of linkage in repulsion phase (Sarsar et al., 1986). Hence, selection of hybrids based on sca effects would excel in their heterotic effect. Similar results were obtained by Dubey and Maurya (2007) and Suganthi (2008) in bottle gourd,
Sarkar and Sirohi (2010) in cucumber, Podder (2010) in snake gourd, Vegad et al., (2011) in bottle gourd, Alli Rani (2013) and Narasannavar (2014) in ridge gourd and Meena (2015) in Indian Mustard found that these yield and yield contributing trait was under the control of non-additive gene action.

Hence, this cross can be utilized for breeding programme to evolve high yielding varieties. The crosses, $\mathrm{L}_{2} \mathrm{xT}_{3}, \mathrm{~L}_{7} \mathrm{xT}_{2}, \mathrm{~L}_{2} \mathrm{xT}_{4}, \mathrm{~L}_{5} \mathrm{xT}_{1}$, and $\mathrm{L}_{8} \mathrm{XT}_{4}$ recorded significant sca effects and the gene action might be of additive type of epistasis. These crosses also can be utilized for breeding programme. However, selection should be postponed to later generation due to the presence of additive type of epistatic gene action.

\section{Acknowledgement}

I am very grateful to the University Grants Commission (UGC), New Delhi for providing Fellowship to my Ph.D programme and also thankful to the Director, NBPGR, New Delhi for supplying the seeds of different snake gourd germplasm.

\section{References}

Ahmed, A.M., Reddy, T.P. and Neeraja, G. 2004. Heterosis for fruit yield and yield components in ridge gourd [Luffa acutangula (Roxb.) L.]. J. Res. Angrau., 34(1): 15-20.

Alli Rani, E. 2013. Genetic studies on growth, yield and mosaic tolerance in Ridge Gourd [Luffa actuangula L. (Roxb)]. M.Sc., (Hort.) Thesis, Tamil Nadu Agricultural University, Coimbatore.

Bairwa, S.K., Soni, A.K., Singh, B. and Yadav, P.K. 2015. Combining ability studies in Ridge Gourd [Luffa acutangula (Roxb.) L.]. The Bioscan, 10(4): 1969-1974. 
Banga, S.S. 2012. Germplasm Enhancement in Indian Mustard: Some Exiting New Developments. In: "Souvenir of XIX Annual AICRP Group Meet on Rapeseed-Mustard", Birsa Agricultural University, Ranchi, India, pp. 29-34.

Dubey, S.K. and Maurya, I.B. 2007. Combining ability for character related to yield and earliness in Bottle Gourd [Lagenaria siceraria (Mol.) Standl.]. Indian J. Agri. Res., 4(1): 59-62.

Kempthorne, O. 1957. An Introduction to Genetic Statistics. J. Wiley and Sons, Inc., New York.

Meena, H. S., Kumar, A., Ram, B., Singh, V. V., Meena, P. D., Singh, B. K. and Singh, D. 2015. Combining ability and heterosis for seed yield and its components in Indian Mustard (Brassica juncea L.). J. Agr. Sci. Tech. 17: 1861-1871.

Narasannavar, A.R., Gasti, V. D., Shantappa, T., Mulge, R., Allolli, T. B. and Thammaiah, N. 2014. Heterosis studies in Ridge Gourd [Luffa acutangula (L.) Roxb.] Karnataka J. Agric. Sci., 27 (1): (47-51)

Pali, V and Mehta, N. 2014. Combining ability and heterosis for seed yield and it's attributes in Linseed (Linum usitatissimum L.). The Bioscan. 9(2): 701-706.
Podder, R., Rasul, M. G., Islam, A.K.M.A., Mian, M.A.K. and Ahmed, J. U. 2010. Combining ability and heterosis in Snake Gourd (Tricosanthes cucurminata L). Bangladesh J. Pl. Breed. Genet., 23(2): 01-06.

Rao, E.S., Munshi, A.D. and Verma, V.K. 2004. Genetic association and inter relationship of yield and its components of Cucumber (Cucumis sativus L.). Indian J. Hort., 64(4): 315-318.

Sarkar, M. and Sirohi, P.S. 2010. Combining ability analysis for yield and its attributing character in Cucumber. Indian J. Hort., 67(4): 525-530.

Sarsar, S.M., Patil, B.A. and Bhatade, S.S. 1986. Heterosis and combining ability in upland cotton. Indian J. Agric. Sci., 56 (8): 567-573.

Singh, A.K., Pan, R.S. and Bhavana, P. 2013. Heterosis and combining ability analysis in Bitter Gourd (Momordica charantia L.). The Bioscan, 8(4): 15331536.

Suganthi, M. 2008. LxT analysis in Bottle Gourd [Lagenaria siceraria (Mol.) Stand]. M.Sc. Thesis. Tamil Nadu Agricultural University, Coimbatore.

Vegad, P.M., Vaddoria, M.A., Mehta, D.R. and Naghera, Y.V. 2011. Combining ability analysis in Bottle Gourd. Crop Improvement, 38(1): 13-17.

\section{How to cite this article:}

Deepa Devi, N., S. Mariappan, T. Arumugam and Anandakumar, C.R. 2017. Estimating Combining Ability for Yield and Yield Contributing Traits in Snake Gourd (Trichosanthes cucumerina L.). Int.J.Curr.Microbiol.App.Sci. 6(2): 795-800.

doi: http://dx.doi.org/10.20546/ijcmas.2017.602.088 